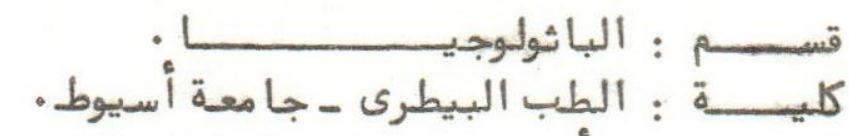

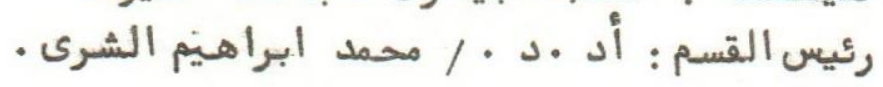

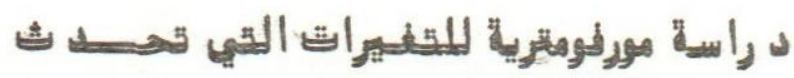

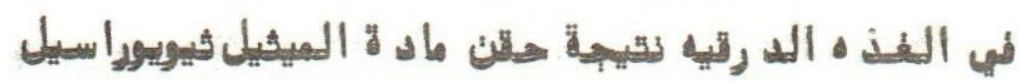

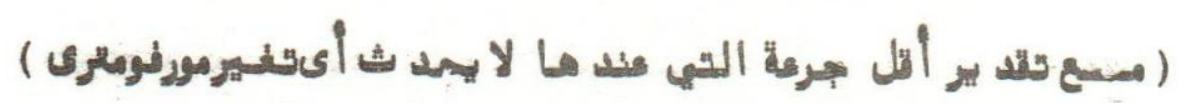

\title{
مجمسـ هـ
}

أجرى هذا البحث لتقد ير أقل جرعه من ماد الم الميثيــــــــــلـل

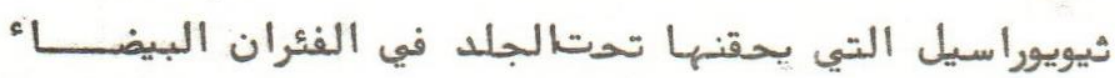

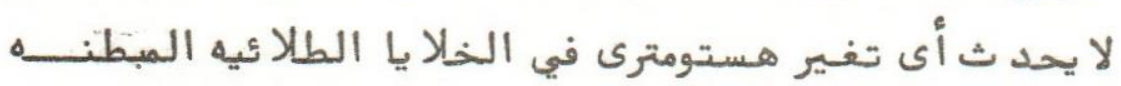

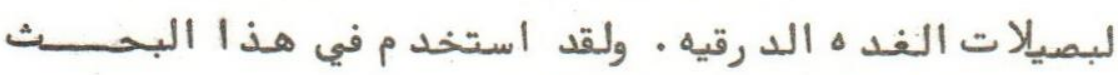

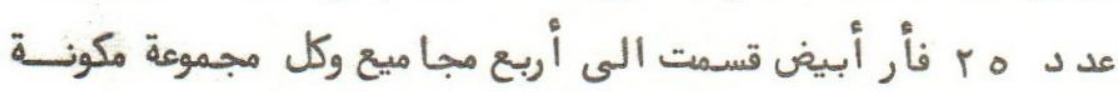

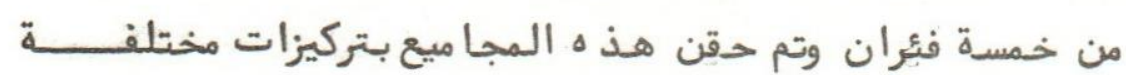

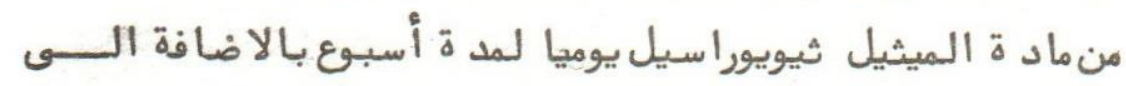
المجموعه الخامسة التي لم تحقن واستخد مت للمقارنة .

ولقد اتضح أنه عند حقن الفئران بتركيز(0 •ر مليجرام)مســن

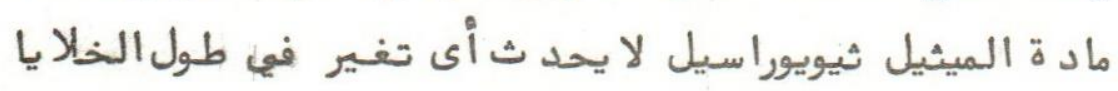

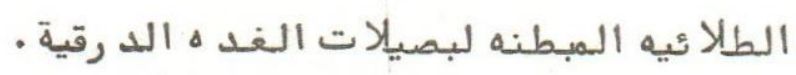

ولقد اتضح منالد راسة المورفومترية أنه بحقن الفئران بتركيز

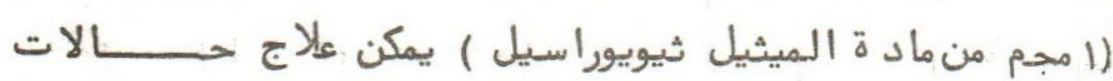

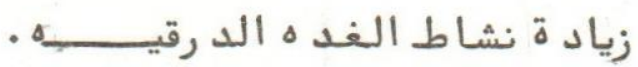


Dept. of Pathology,

Faculty of Vet. Med., Assiut University,

Head of Dept. Prof. Dr. M.I. El-Sherry.

\title{
EXPERIMENTAL STUDY OF HYPOTHYROIDISM IN RATS WITH SPECIAL REFERENCE TO THE NO-EFFECTIVE DOSE
} (With 1 Table \& 1 Histogram)

\author{
By \\ M.K. IBRAHIM \\ (Received at 13/3/1983)
}

\begin{abstract}
SUMMARY
The present work was designed to determine the dose at which no morphometrical changes occur in the epithelial linning of the follicles in the thyroid gland of rats experimentally injected with antithyroid drug Methyithiouracil ( $M \quad T U$ ). Twenty-five rats were used in the present experiment. They were divided into four groups $A, B, C$, and $D$ of 5 animal each and were injected with $(M T U$ ) at a dose level of $0.5,0.1,0.05$ and $0.02 \mathrm{mg}$. per $\mathrm{kg}$. body weight respectively. In addition, a fifth group "E" of 5 animal was used as a control. It was found that at a dose level of $0.05 \mathrm{mg}$. (M T U) per $\mathrm{kg}$. body weight, no morphometrical changes occur in the epithelial linning of the thyroid follicles. Accordingly, a dose of $0.1 \mathrm{mg}$. (M T U) per $\mathrm{kg}$. body weight is to be recommended for treatment of hyperthyroidism or to prepare a hypothroid rat-model for comparative pathology.
\end{abstract}

\section{NTRODUCTION}

The functional state of the thyroid is assessed by different ways including morphometrical, clinical and biochemical methods. Morphometrical study as a method for testing a medicament and chemical substance was proved to be the best one when compared with the biochemical and pharmacological methods (MESSOW et al. 1973). In an earlier work (IBRAHIM 1981), we found that treatment of rats with a dose level of $0.1 \mathrm{mg}$. per $\mathrm{kg}$. body weight of methylthiouracil induced morphometrical changes in the epithelial cells that lined the follicles of the thyroid gland compared with controls. In the present work we tried to determine the dose at which no morphometrical changes occur in the epithelial linning of the follicles in the thyroid gland of rats which have been adminstered this compound.

\section{MATERIAL. and METHODS}

In the present work 25 wistar** rats (250-300 gm. body weight) were manipulated under enviromental condition of $22^{\circ} \mathrm{C}$ room temperature and were rationed ad libithum and adequatly supplied with tap water. The animals were regularly exposed to light for 12 hours per day. The rats were divided into 5 groups $A, B, C, D$, and $E$ of 5 animal each. The animals were individually treated daily with subcutaneous injection of 6 hydroxy-2-mercapto-4-Methyl pyramidin, MethyIthiouracil (M $T U$ ) for one week at dose level of $0.5,0.1,0.05$ and $0.02 \mathrm{mg}$. per kg. body weight for group $A, B, C$ and D respectively. In addition a fifth group "E" of 5 animals was used as a control.

* This experiment was done at the institute of pathology, Hannover (W G).

Assiut Vet. Med. 1. Vol. 12, No. 24, 1984. 


\section{MK. IBRAHIM}

The thyroid glands were collected from the rats after they were sacrificed (by decapitation) and were fixed in 10\% neutral buffer formalin. Paraffin sections, 4-5 micron thickness, were stained with haematoxlin and eosin. The histometrical parameter empolyed was measuring the height of the epithelial cells linning the follicles of the thyroid gland. The histological slide was then projected on a screen using a "karl zeiss" microscope to obtain a magnification of 500 fold. Each thyroid was represented in 5 serial sections. From each animal the epithelial height of 50 follicles located centrally and 50 other follicles located peripherally were measured. Statistical methods were carried out to postulate the changes given in each test. The mean values of each measurement for different groups were statistically analysed.

\section{RESULTS}

Data of the morphometrical parameters of the epithelial linning of the thyroid follicles was shown in table 1 and represented in histogram 1. Statistical analysis of these data revealed a high significant increase $(P /$ 0.001) of the average value of the epithelial height in group A which has been given the high dose of $M T U$ as compared with the control group. Group $B$ revealed also a significant increase of the average value of the epithelial height $(P / 0.01)$ as compared with control. These significant changes of the epithelial height were prominent in the centre of the gland as well as in the peripherally located follicles (group A and B). Both group $C$ and $D$ showed no significant changes of the epithelial height either centrally or peripherally as compared with the control group.

\section{DISCUSSION}

The functional activity of the thyroid gland can be determined by different means, one of which is histometry. SELYE (1953) and MESSOW et al. (1973) stated that the epithelial height reflects the functional state of the gland. METTHIESEN, et al. (1975) found moreover that, when compared with the biochemical finding, the epithelial height as a histological parameter was more sensitive in Wistar rats treated with oral application of M T U.

In the present work we used different dose-levels of $M T U$ in an attempt to determine the "no-effective level", ie, the dose at which no morphometrical changes occur in the thyroid gland. HANSEN (1977), by oral application of M T U, found that in Wistar rats the "no-effective level" was $0.5 \mathrm{mg}$. per $\mathrm{kg}$. body weight. In the present work we have found that subcutaneous injection of $M T U$ at a dose of $0.05 \mathrm{mg}$. per $\mathrm{kg}$. body weight induced no morphometrical changes in the rat thyroid. The difference between our results and that of HANSEN (1977) is related most probably to the route of administration and emphasized the conclusion of KOPF (1952) that the effect of antithyroid drug depends not only on the dose but also on its duration and route of application. By oral administration, the small intestine metabolised large amount of M T U before reaching the blood (BRUGGEMANN et al. 1952) and therefore, higher doses are required.

Accordingly, a dose level of $0.1 \mathrm{mg}$. M T U per $\mathrm{kg}$. body weight (the dose above the no-effective level; group B) is recommended for treatment of hyperthyroidism or preparing a hypothyroidised rat-model for experimental comparative pathology. Our results are of importance from the point of view that at this low level other side-effects of the drug can be minimized to the greatest extent. 
In the present study, the location difference of the epithelial reaction has been taken in consideration. Our result showed that the epithelial cells that lined the centrally located follicle reacted more clearly than those located peripherally (Histogram 1). This is similar to that recorded by MESSOW et al. (1973) and HANSEN (1977). These location difference may be related to variations in the concentration of iodine in different parts of the thyroid gland. NADLER (1954) stated that the thyroid gland of children is greatly resembling those of rats and found that high absorption of iodine occurs more in the centre of the gland.

\section{REFERENCES}

Bruggemann, J.; J. Schole and H. Vogel (1952): Beitrage zür frage der Verwendung von Masthilfsmitteln. Landwirtschaft. Jarbuch fur Bayer 29, 511.

Hansen, H. (1977): Artspezifische quantitative Reaktionunterschiede der schilddruse von Ratte, Maus, Meerschweinchen und kaninchen bei M T U - Applikation. Diss., Tierarztliche, Hochschule Hannover.

Ibrahim (1981): Histometrische schilddrüsenveranderungen nach subkutaner Applikation von methyIthiouracil bei Ratten.

Kopf, R. (1952): Experimentelle Grundlagen der therapeutischen Anwendung antithyroidaler Schwefelverbindungen. Arzneimmittelforschung 2, 145-152, 235-245, 315-324.

Matthiesen, T.; C. Messow; H.P. Kolm and R. Kodding (1975): Experimenteller Beitrag zur frage des Zusammenhangs zwischen Funktion and Morphlogie der Ratten Schilddrüse nach Applikation von Methylthiouracil und thyreotropen Hormone. Arzneimittelforschung (Drug. Res.) 25, 68-71.

Messow, C.; T. Matthiesin and J. Dycka (1973): Vergleich, histometrischer Parameter an Rattenschilddrüsen nach Verabreichung von Methylthiouracil. Arzneimmittel forschung 33, 1076-1079.

Nadler, U.J.; C.P. Leblond and R. Begeroch (1954): The rate of iodine metabolism by the thyroid follicles as function of its size. Endocrinology 54, 154-172.

Selye, H. (1953): Einfuhrung an die Lehre von Adaptationssyndrom G. Thieme, Stuttgart.

Table (1)

Relative measures of epithelial height (central and peripheral)

\begin{tabular}{ccccc}
\hline \multirow{2}{*}{ Groups } & $\bar{x}$ & S.D & $\bar{x}$ & S.D \\
\cline { 2 - 4 } & central & central & peripheral & peripheral \\
\hline A & $11.032^{x \times x}$ & \pm 0.323 & $8.420 \times x \times$ & \pm 0.458 \\
B & $7.940^{x \times}$ & \pm 0.235 & 5.490 & \pm 0.073 \\
C & 7.336 & \pm 0.018 & 4.940 & \pm 0.038 \\
D & 7.432 & \pm 0.043 & 4.950 & \pm 0.025 \\
Control & 7.100 & \pm 0.284 & 5.160 & \pm 0.085 \\
\hline
\end{tabular}

$\bar{x} \quad=$ mean
S.D $\quad$ standard deviation
$x=P / 0.05$

$x=P$ / $0.05 \quad x x=P / 0.01 \quad x x x=P / 0.001$ 

Epithelial-height (relative velue in $\mathrm{mms}$ )

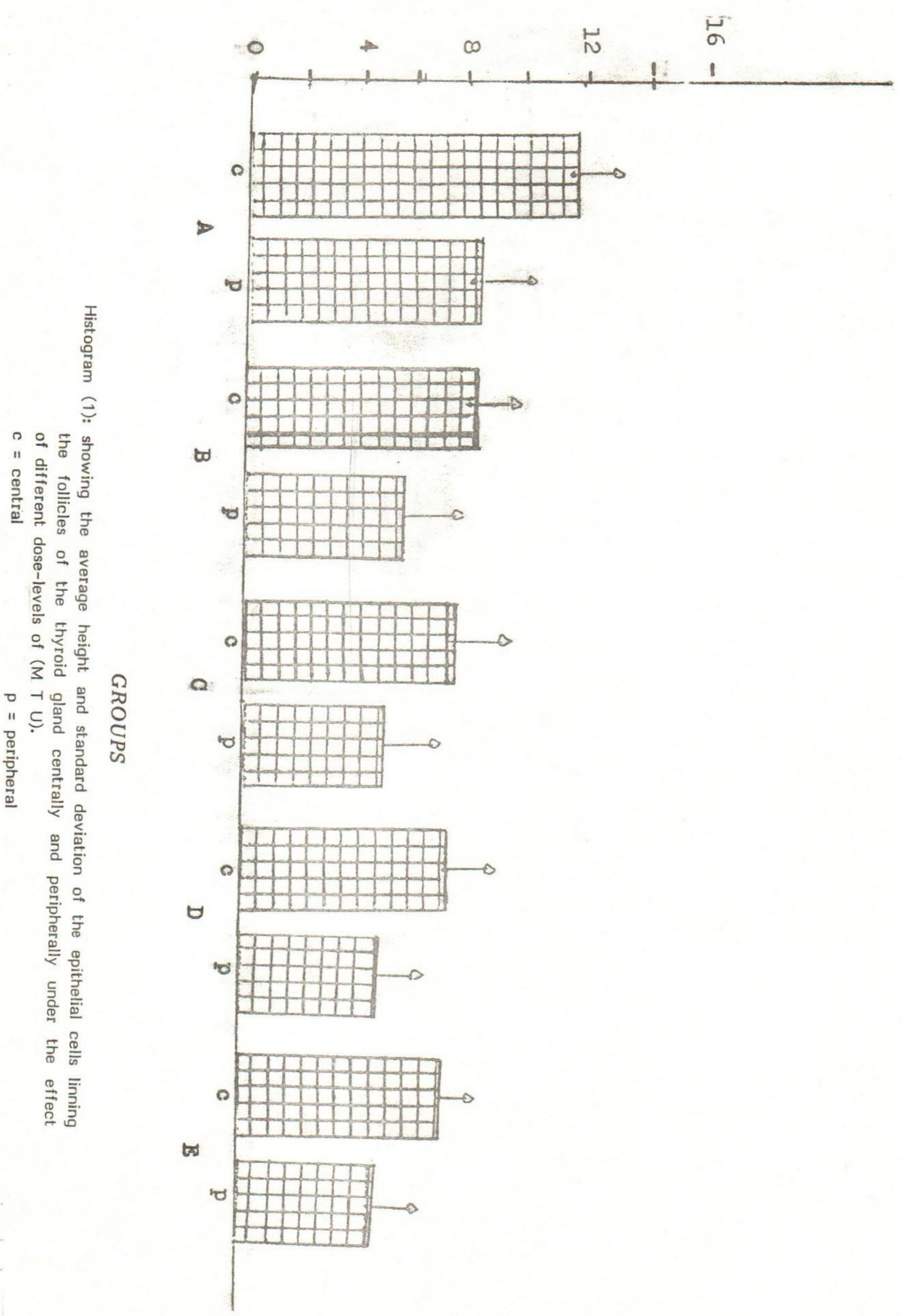


